\title{
Molecular Biology of Vitaceae using DNA Markers: A Review
}

\author{
Nasheez Fatma \\ P.G. Department of Botany, T. M. Bhagalpur University, Bhagalpur
}

\begin{abstract}
Vitaceae is the only family of the predominantly tropical order Vitales. The phylogenetic position of Vitaceae has been variously hypothesized prior to APG III (2009). Relationships of Vitaceae to other families have long been highly speculative and variable. Recently there are 14 accepted genera of Vitaceae with their species strength c. 978 (sensu APG III, 2009). The phylogeny of Vitaceae has been reconstructed with several markers which confines Leea within Vitaceae. The present study defines the review of Vitaceae phylogeny using several DNA markers.
\end{abstract}

Keywords: Phylogeny, Vitaceae, DNA, Markers

\section{Introduction}

Vitaceae is the only family of the predominantly tropical order Vitales. The phylogenetic position of Vitaceae has been variously hypothesized prior to APG III (2009). Relationships of Vitaceae to other families have long been highly speculative and variable. According to Chase et al. (1993) Vitaceae + Leeaceae were sister to Dilleniaceae but subsequent analyses (Savolainen et al., 2000a, b; Soltis et al., 2000) with many more data have failed to confirm this placement. Furthermore there was little non-molecular evidence to support such a relationship. According to Chase et al. (1993) Vitaceae were not related to Rhamnaceae as thought earlier. Savolainen et al. (2000a), using $r b c L$ and atpB (both plastid genes), placed Vitaceae/Leeaceae near the base of the large rosid clade, and Soltis et al. (2000) using three genes (the two plastid genes plus nuclear 18S rDNA) obtained Vitaceae (including Leea) as sister to the rest of the rosids with moderate jackknife support. Recent molecular analyses generally supported the Vitaceae clade (including Leeaceae) as sister to all other rosids (Soltis et al., 2000, 2003, 2006; Jansen et al., 2006; Wang et al., 2009). Hillu et al. (2003) on the basis of matK data, suggested that Dilleniaceae is sister to Vitaceae, although support for this relationship varies with the methods applied (weak using MP, but 1.0 PP in BI). APG III (2009) placed Vitaceae as sister to the fabids + malvids clade (eurosids I + II) and recognized it in its own order Vitales following Takhtajan (1977). During early classifications genus Leea has been excluded from Vitaceae and treated as the monogeneric family Leeaceae by Vitaceae/Leeaceae specialists (e.g., Planchon, 1887; Suessenguth, 1953; Ridsdale, 1974; Shetty \& Singh, 2000; Latiff, 2001; Ren et al., 2003; Chen and Manchester, 2007; Wen, 2007a, b). Leeaceae has been supported as the closest relative of Vitaceae based on DNA molecular phylogenetic and morphological data (Soejima \& Wen, 2006; Wen, 2007a, b; Wang et al., 2009). The present study clearly defines that Leea lies within Vitaceae including the 14 genera are Ampelocissus Planch., Ampelopsis Michx, Cayratia Juss., Cissus L., Clematicissus Planch., Cyphostemma (Planch.) Alston, Nothocissus (Miq.) Latiff, Parthenocissus Planch., Pterisanthes Blume, Rhoicissus Planch., Tetrastigma (Miq.) Planch., Vitis L., Yua Li. and Leea (D.C) Dum. The work was carried out using molecular ITS sequences to estimate phylogenetic relationships in
Indian Vitaceae. The materials for the present study were collected from various localities.

The phylogeny of Vitaceae has been reconstructed with several markers (Rossetto et al., 2001, 2002; Ingrouille et al., 2002; Soejima \& Wen, 2006; Wen et al., 2007). With 37 taxa sampled in the combined analyses, Soejima \& Wen (2006) reconstructed the phylogeny of Vitaceae based on three chloroplast markers (trnL-F region, atpB-rbcL spacer, the rps16 intron), which supported three major clades: (1) the Ampelopsis-Rhoicissus-Parthenocissus-VitisNothocissus-Pterisanthes-Ampelocissus clade; (2) the core Cissus clade (except the South American Cissus striata complex); and (3) the Cayratia-Tetrastigma-Cyphostemma clade. Wen et al. (2007) sampled eleven genera and 95 species and infra-specific taxa of Vitaceae to reconstruct the relationships within Vitaceae with the nuclear GAII sequences. The three major clades formerly recognized by Soejima \& Wen (2006) were strongly supported by the GAII data. Particularly, the first clade was $100 \%$ supported by the GAII data compared to a less than $50 \%$ bootstrap (BS) value in the three plastid markers, and a close relationship between the core Cissus clade and the 5-merous clade was well supported. Different from the plastid phylogeny, the GAII data recognized Ampelopsis as the closest relative of Parthenocissus instead of Vitis, although the support values were low.

Rossetto et al. (2007) constructed the phylogeny of Australian Vitaceae using plastid $t r n L-F$ and nuclear internal transcribed spacer sequences. Their data supported a robust sister relationship between Clematicissus and a clade of two South American Cissus (Cissus tweediana (Baker) Planch. and Cissus striata Ruiz \& Pav.) and further supported the paraphyly of Cayratia. Vitaceae are most closely related with monogeneric Leeaceae (Ingrouille et al., 2002) which share several important morphological synapomorphies including presences of pearl gland and raphides makes a reasonable reference point to start describing the trends culminating in Vitis. It is separated from Vitaceae only on the basis of its non-vining habit (Ingrouille et al., 2002).

Traditionally it was considered in the order Rhamnales (Kirchheimer, 1939; Cronquist, 1981, 1988). Takhtajan (1977) recognized order Vitales consisting of Vitaceae as

\section{Volume 5 Issue 2, February 2016}




\section{International Journal of Science and Research (IJSR) \\ ISSN (Online): 2319-7064}

Index Copernicus Value (2013): 6.14 | Impact Factor (2014): 5.611

highly isolated and the sole member of the superorder Vitanae in the Rosidae. Most workers excluded Leea from Vitaceae and recognized the family Leeaceae (Shetty and Singh, 2000; Lattif 2001a; Ingrouille et al., 2002; Rossetto et al., 2002c; Ren et al.,2003; Soejima and Wen, 2006). Various important taxonomic studies of Vitaceae have been produced, emphasizing the taxa of particular regions. These include the treatments of Gagnepain (1911a, 1919), Lattif (1981, 1982, 1983, 1991, 2001a, 2001b), and Mabberley (1995) on species in southeast Asia/Malaysia; Jackes (1984, 1987a, 1988a, 1989a, 1989b). Jackes and Rossetto (2006) studied the Australian species. Wang et al. (1999, 2009), and Li's (1998) treatments of Vitaceae in China; Shetty and Singh's (2000) study of Indian species; Vassilczenko's (1970) treatment of Vitaceae in Iran; Gilg and Brandt's (1911), Dewit and Willems's (1960), Wild and Drummond's (1966), Descoings's (1967a) and Verdcourt's (1993) treatment of species in Africa and Madagascar; Lombardi's (2000) of South American species, Brizicky (1965), Galet (1967) and Moore $(1987,1991)$ worked on several species of temperate North America regions. In these taxonomic treatments, 77 genera were mainly differentiated based on floral structures like petal number, calyptras, styles, nectariferous disc, inflorescence, fruits and seed morphology. Species were often distinguished by variations in vegetative structures, mostly by different leaf forms and indument conditions and suction pads on the tips of the tendrils.

Comparative developmental morphology of floral and vegetative structures of Vitaceae have been extensively carried out by Gerrath and colleagues (Posluszny and Gerrath, 1986; Gerrath and Posluszny, 1988a, 1988b, 1989a, 1989b, 1989c; Lacroix and Posluszny, 1989a; Gerrath, Lacroix, and Posluszny, 1990; Gerrath and Posluszny, 1993; Gerrath and Lacroix, 1997; Gerrath, Lacroix, and Posluszny, 1998; Gerrath, Posluszny and Dengler, 2001; Wilson and Posluszny, 2003a, 2003b; Gerrath, Wilson and Posluszny, 2004; Gerrath and Posluszny, 2007; Timmons, Posluszny and Gerrath, 2007a, 2007b).

Besides this Kirchheimer 1939, and Tiffney and Barghoorn (1976) suggested that the fossil seed records of the family are easily recognized from a suite of unique and distinctive morphological characters like a pair of ventral infolds and a dorsal chalazal scar and are relatively common in tertiary floras. The infra-familial relationships are often reflected by the morphological variation among fossil seeds of the family. They considered that Vitaceous seeds can be differentiated at the generic level but with limited sampling of the extent species intrageneric variation has not been fully explored because of the lack of modern Vitaceous seed representatives. It is suggested that the evolutionary and phytogeographic history of the family influenced the seeds of the extent genera which provide a good basis for interpretation among basal rosid families.

In the APG III (2009) classification, Soltis et al. (2000) placed Vitaceae sister to the rest of the rosids. This current account of Angiosperm Phylogeny shows 978 species distributed under 14 genera of the family. These 14 genera identified excluded Acareosperma and included Leea in APG III, 2009.

\section{Material and Methods}

The present work includes genomic DNA extraction, PCR amplification and sequencing of amplified products and phylogenetic analysis. Of all the 14 identified genera, the sampling includes sequences of 6 genera and 15 species which well represent the taxonomic diversity of the family. Sequences were aligned using ClustalX vers. 2.0.11 (Thompson et al. 1997) followed by manual adjustments in ClustalW (Thompson et al. 1994).

\section{Observation and Results}

The present analyses involved 128 nucleotide sequences (including outgroups). Sequences comprised of ITS1, 5.8S and ITS2 regions. Forward and reverse sequences were edited and assembled using the computer program Codon Code Aligner vers. 3.7.1. (2002-2009, Codon code corp.) and DNA Baser (vers. 3) (2011). The combined length of the entire ITS region (ITS1, 5.8S and ITS2) from taxa sampled in the present study ranged from 594-658 nucleotides. The ITS1 region ranged from 200-245 nucleotides in length, the $5.8 \mathrm{~S}$ gene was of 175 nucleotides, and the ITS2 region ranged from 220-285 nucleotides. All positions containing gaps and missing data were eliminated. The insertions and deletions (indels) were necessary to align the sequences. The sizes of the indels ranged from 1 to $20 \mathrm{bp}$. There were a total of 1142 positions in the final dataset. Phylogenetic analyses were done using Bayesian (Maximum Posterior Probability, MPP), Maximum Parsimony (MP) and Neighbour-Joining (NJ) methods. Bayesian analyses were done using MrBayes 3.1. Analyses were run for 30,00,000 generations by which stage the stationary state was achieved (standard deviation below 0.01). An analysis of a total of 58 accessions of DNA sequences representing 9 genera and 33 species of Vitaceae has been done. The present work reviews the data on different markers used in phylogenetic analysis of Vitaceae (Table 1). The results may be used as evidence to support the phylogenetic conflicts.

\section{References}

[1] Angiosperm Phylogeny Group, 2009. An update of the Angiosperm Phylogeny Group Classification for the order and families of flowering plants APG III. Bot. J. Linn. Soc. 161: 105 - 121.

[2] Fatma, N. 2015: Molecular systematic study of Vitaceae using ITS sequences of nr DNA Ph.D Thesis.

[3] GRIN: USDA, ARS: National Genetic Resource Program. Germplasm resources Information Network(GRIN) [Online Database]. National Germplasm Resources Laboratory, Beltsville, Marryland. [http://www.ars-grin.gov./cgibin/npgs/html/tax_search.Pl>

[4] Hilu, W. K.; Borsch, T.; Mullar, K.; Soltis, D. E.; Savolainen, V.; Chase, M. W.; Powell, M. P.; Alice, L. A.; Evans, R.; Sauquet, H.; Neinhuis, C.; Slotta, T. A. B.; Rohwer, J. G.; Campbell, C. S. and Chatrou, L. W. 2003. Angiosperm phylogeny based on matK sequence information. Amer. J. Bot. 90(12): 1758-1776.

[5] Ingrouille, M.; Chase, M.; Fay, M.; Bowman, D.; Van der Bank, M. and Bruijn, A. 2002. Systematics of 


\section{International Journal of Science and Research (IJSR) \\ ISSN (Online): 2319-7064}

Index Copernicus Value (2013): 6.14 | Impact Factor (2014): 5.611

Vitaceae from the viewpoint of plastid $r b c L$ DNA sequence data. Bot. J. Linn. Soc. 138: 421-432.

[6] IPNI [International Plant Names Index]. 2008. Published on the Internet http://www.ipni.org [accessed November 2008]. Collaboration between the Royal Botanic Gardens, Kew, Harvard University Herbaria, and the Australian National Herbarium.

[7] Jackes, B.R. and Rossetto, M. 2006. A new combination in Clematicissus PLanch. (Vitaceae). Telopea. 11(3):390-391.

[8] Nie, Z.L.; Sun, H.; Chen, Z.D.; Meng, Y.; Manchester, S.R. \& Wen, J. 2010. Molecular phylogeny and biogeographic diversification of Parthenocissus (Vitaceae) disjunct between Asia and N. America. Amer. J. Bot. 97: 1342-1353.

[9] Peros, J. P.; Berger, G.; Portemont, A.; Boursiquot, J.M. and Lacombe, T. 2011. Genetic variation and biogeographic diversification of Parthenocissus (Vitaceae) J. Biogeo. 38: 471-486.

[10]Ren, H.; Lu, L. M.; Soejima, A.; Luke, Q.; Zhang, D.; Chen, Z. \& Wen, J. 2011. Phylogenetic analysis of the grape family (Vitaceae) based on the non-Coding plastid trnC-petN, trnH-psbA and trnL-F sequences. Taxon 60(3): 629-637.

[11] Rossetto, M.; Jackes, B.; Scott, K. D. and Henry, R. J. 2001a. Intergeneric relationships in the Australian Vitaceae: new evidence from cpDNA analysis. Gen. Res. Crop Evol. 48: 307-314.

[12] Rossetto, M.; Jackes, B.; Scott, K. D. and Henry, R.J. 2001b. Evaluating the poteintial of SSR flanking regions for examining taxonomic relationships in Vitaceae. Theo. Appl. Genet 103: 61-66.

[13] Rossetto, M.; Jackes, B.; Scott, K. D. \& Henry R. J. (2002) Is the genus Cissus (Vitaceae) monophyletic: evidence from plastid and nuclear ribosomal DNA. Syst. Bot. 27: 522-533.

[14] Rossetto, M.; Crayn, D. M.; Jackes, B. R. and Porter, C. 2007. An updated estimate of intergeneric phylogenetic relationships in the Australian Vitaceae. Can. J. Bot. 85: 722-730.

[15] Soejima, A. and Wen. J. 2006. Phylogenetic analysis of the grape family (Vitaceae) based on three chloroplast markers. Amer. J. Bot. 93: 278 - 287.

[16]USDA NRCS. 1999. The PLANTS database (www.plants.usda.gov). National Plant Data Center, Baton Rouge, LA 70874-4490 USA.

[17] Soltis, D. E.; Soltis, P. S.; Chase, M. W.; Mort, M. E.; Albach, D. C.; Zanis, M.; Savolainen, V. 2000. Angiosperm phylogeny inferred from 18S rDNA, $r b c L$, and $a t p B$ sequences. Bot. J. Linn. Soc. 133: 381- 461.

[18] Soltis, D. E.; Smith, S. A.; Cellinese, N.; Wurdack, K. J.; Tank, D. C.; Brockington, S. F.; Refulio-Rodriguez, N. F.; Walker, J. B.; Moore, M. J.; Carlsward, B. S.; Bell, C.D.; Latvis M.; Crawley, S.; Black, C.; Diouf, D.; Xi, Z.; Rushworth, C. A.; Gitzendanner, M. A.; Sytsma, K. J.; Qiu, Y. L.; Hilu, K. W.; Davis, C. C.; Sanderson, M. J.; Beaman, R. S.; Olmstead, R. G.; Judd, W. S.; Donoghue, M. J. and Soltis, P. S. 2011. Angiosperm Phylogeny: 17 Genes, 640 Taxa. Amer. J. Bot. 98(4): 704-730.

[19] Trondle, D. Schroder, S.; Kassemeyer, H.-H.; Kiefer, C.; Koch. M. A., Nick, P., 2010. Molecular phylogeny of the genus Vitis (Vitaceae) based on plastid markers. Amer. J. Bot. 97:1168-1178.

[20] Wang, Y.; Chen, J.; Lu, J. and Lamikanra, O. 1999. Randomly amplified polymorphic DNA analysis of Vitis species and Florida bunch grapes. Scientia Horticulturae 82, 85-94.

[21] Wen, J.; Nie, Z. L.; Soejima, A. and Meng, Y. 2007. Phylogeny of Vitaceae based on the nuclear GAI1 gene sequences. Can. J. Bot. 85: 731-745.

[22]Zecca, G.; Richard, J.; Abbott, Wei-B.; Spada, S. A.; Sala, F.; Grassi, F., 2012. The timing and the mode of evolution of Wild grapes (Vitis). Mol. Phyl. Evol. 62: 736-747.

Table 1: Vitaceae genera with DNA data including Leeaceae. (key to the type of molecular data $1=r b c L, 2=m a t K, 3=S S R$, $4=\operatorname{rps} 16,5=r p l 2-t r n H, 6=\mathrm{ITS}, 7=G A I 1,8=\operatorname{trnR}-r r n 5$ spacer , 9= trnC-pet $N, 10=26 \mathrm{~S}$ rRNA, 11= rps 16, 12=trnL-trnF, 13= $r p l 32-\operatorname{trn} L, 14=18 \mathrm{~S}$ rRNA, 15=trnK-rps 16, 16=atpB, 17=atpB-rbcL, 18=rps16-trnQ, 19=trnK-matK, 20=rpoB, 21=rps2,

$22=\operatorname{trnR}$-atp $A, 23=r p o C 1,24=a c c D, 25=\mathrm{ITS} 1-5.8 \mathrm{~S}$ 26=ITS1, 27=trnS-trnG, 28=rpl20-rps 12, 29=trnL, 30=trnH-psbA,

31=trnH-psbA-trnK, 32=trnF-nahJ, 33=18S-26S rRNA-atpB-matK-ndhF-psbBTNH-rbcL-rpoC2-rps4-atp1-matR-nad5-rps3.

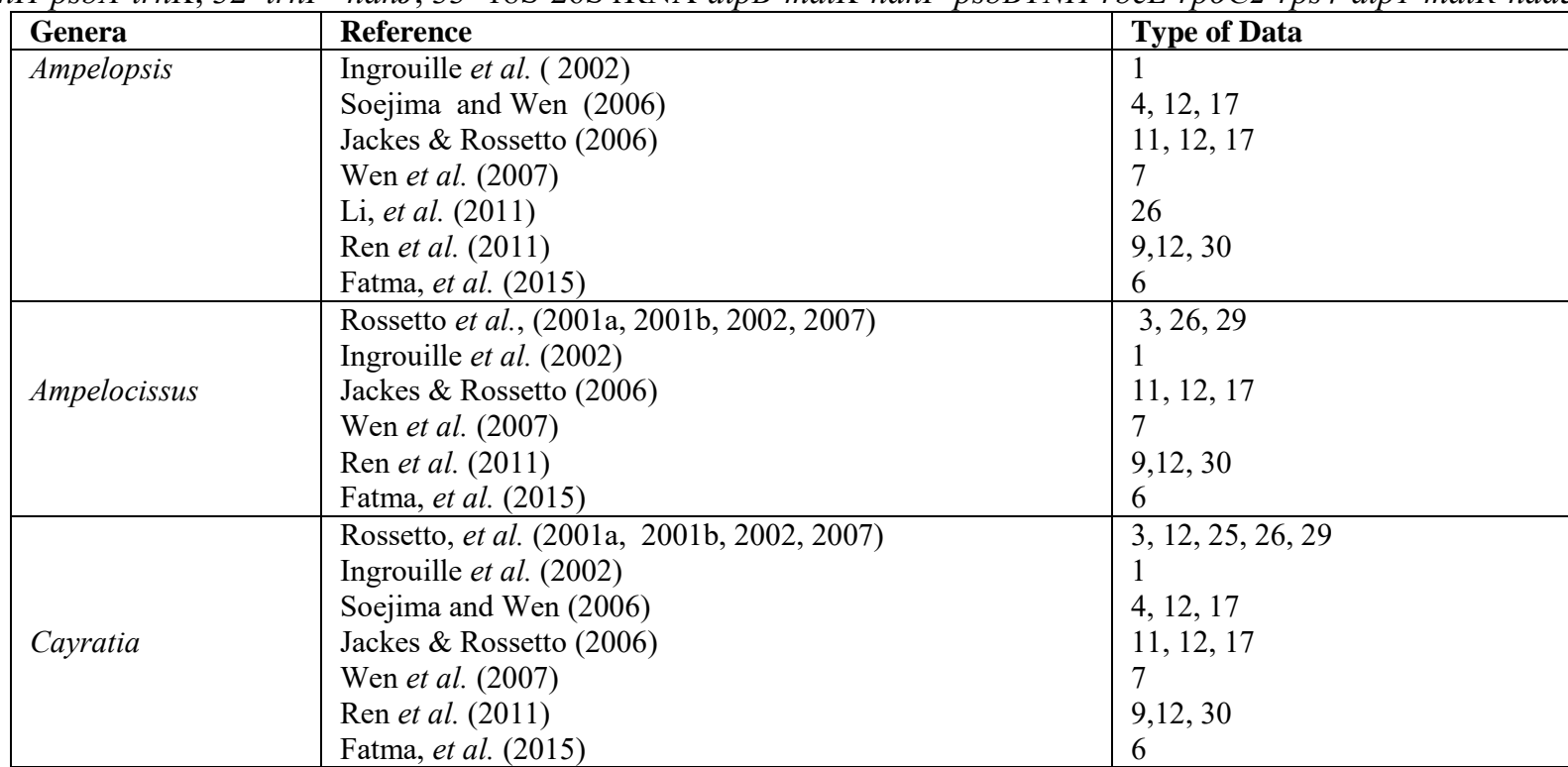

Volume 5 Issue 2, February 2016 
International Journal of Science and Research (IJSR)

ISSN (Online): 2319-7064

Index Copernicus Value (2013): 6.14 | Impact Factor (2014): 5.611

\begin{tabular}{|c|c|c|}
\hline Genera & Reference & Type of Data \\
\hline Cissus & $\begin{array}{l}\text { Rossetto et al. (2001a, 2001b, 2002, 2007) } \\
\text { Ingrouille et al. }(2002) \\
\text { Jackes \& Rossetto (2006) } \\
\text { Wen et al. }(2007) \\
\text { Ren et al. }(2011) \\
\text { Fatma, et al. }(2015)\end{array}$ & $\begin{array}{l}3,12,25,26,29 \\
1 \\
11,12,17 \\
7 \\
9,12,30 \\
6\end{array}$ \\
\hline Parthenocissus & $\begin{array}{l}\text { Ingrouille } \text { et al. }(2002) \\
\text { Soejima and Wen (2006) } \\
\text { Jackes \& Rossetto (2006) } \\
\text { Wen } \text { et al. }(2007) \\
\text { Nie } \text { et al. }(2010) \\
\text { Ren } \text { et al. }(2011)\end{array}$ & $\begin{array}{l}1 \\
4,12,17 \\
11,12,17 \\
7 \\
4,7,12,17 \\
9,12,30 \\
\end{array}$ \\
\hline Tetrastigma & $\begin{array}{l}\text { Rossetto et al. }(2001 \mathrm{a}, 2002,2007) \\
\text { Ingrouille et al. }(2002) \\
\text { Soejima and Wen }(2006) \\
\text { Jackes \& Rossetto }(2006) \\
\text { Wen } \text { et al. }(2007) \\
\text { Ren et al. }(2011) \\
\text { Fatma, et al. }(2015)\end{array}$ & $\begin{array}{l}3,12,25,26,29 \\
1 \\
4,12,17 \\
11,12,17 \\
7 \\
9,12,30 \\
6\end{array}$ \\
\hline Cyphostemma & $\begin{array}{l}\text { Ingrouille } \text { et al. }(2002) \\
\text { Soejima and Wen (2006) } \\
\text { Jackes \& Rossetto (2006) } \\
\text { Wen et al. }(2007) \\
\text { Ren et al. }(2011) \\
\end{array}$ & $\begin{array}{l}1 \\
4,12,17 \\
11,12,17 \\
7 \\
9,12,30 \\
\end{array}$ \\
\hline Clematicissus & $\begin{array}{l}\text { Ingrouille et al. }(2002) \\
\text { Rossetto et al. }(2002,2007) \\
\text { Wen } \text { et al. }(2007)\end{array}$ & $\begin{array}{l}1 \\
3,12,25,26 \\
7\end{array}$ \\
\hline Rhoicissus & $\begin{array}{l}\text { Ingrouille et al, (2002) } \\
\text { Soejima and Wen (2006) } \\
\text { Jackes \& Rossetto (2006) } \\
\text { Wen et al. (2007) } \\
\text { Ren } \text { et al. (2011) }\end{array}$ & $\begin{array}{l}4,12,17 \\
1 \\
11,12,17 \\
7 \\
9,12,30\end{array}$ \\
\hline Yua & $\begin{array}{l}\text { Wen et al. }(2007) \\
\text { Ren et al. }(2011)\end{array}$ & $\begin{array}{l}7 \\
9,12,30\end{array}$ \\
\hline Nothocissus & $\begin{array}{l}\text { Soejima and Wen (2006) } \\
\text { Jackes \& Rossetto (2006) } \\
\text { Wen et al. (2007) } \\
\text { Ren et al. (2011) }\end{array}$ & $\begin{array}{l}4,12,17 \\
11,12,17 \\
7 \\
9,12,30 \\
\end{array}$ \\
\hline Pterisanthes & $\begin{array}{l}\text { Soejima and Wen (2006) } \\
\text { Jackes \& Rossetto (2006) } \\
\text { Wen et al. (2007) } \\
\text { Ren et al. }(2011) \\
\end{array}$ & $\begin{array}{l}4,12,17 \\
11,12,17 \\
7 \\
9,12,30 \\
\end{array}$ \\
\hline Vitis & $\begin{array}{l}\text { Trondle et al. }(2010) \\
\text { Ingrouille } \text { et al. }(2002) \\
\text { Rossetto et al. }(2002,2007) \\
\text { Hillu et al. }(2003) \\
\text { Soejima and Wen }(2006) \\
\text { Wen } \text { et al. }(2007) \\
\text { Peros et al }(2011) \\
\text { Ren et al. }(2011) \\
\text { Zecca et al. }(2012) \\
\text { Fatma, et al. }(2015)\end{array}$ & $\begin{array}{l}12,31 \\
1 \\
4,12,17,29 \\
2 \\
1,11,12,17 \\
7 \\
29,31 \\
9,12,30 \\
13,15,30,32 \\
6 \\
\end{array}$ \\
\hline Leea & $\begin{array}{l}\text { Chase } \text { et al. }(1993) \\
\text { Ingrouille } \text { et al. }(2002) \\
\text { Soejima and Wen (2006) } \\
\text { Ren } \text { et al. }(2011) \\
\text { Rossetto et al. }(2002) \\
\text { Savolainen } \text { et al. }(2000 \mathrm{a}) \\
\text { Soltis et al. } 2000,2011 \\
\text { Wen } \text { et al. }(2007) \\
\text { Fatma, et al. }(2015)\end{array}$ & $\begin{array}{l}1 \\
1 \\
4,12,17 \\
9,12,30 \\
25,26 \\
17 \\
14,17,33 \\
7 \\
6\end{array}$ \\
\hline
\end{tabular}

Volume 5 Issue 2, February 2016 